\title{
Growth of Rice Varieties in Different Kenyan Soil Types Under Water-Deficit Conditions
}

\author{
Magoti Rahab ${ }^{1,2}$, Mayumi Kikuta ${ }^{3,4}$, George Chemining'wa ${ }^{2}$, Josiah Kinama ${ }^{2}$, John Kimani ${ }^{5}$, \\ Hiroaki Samejima ${ }^{3,6}$, Patrick Gicheru ${ }^{1} \&$ Daigo Makihara ${ }^{3}$ \\ ${ }^{1}$ Kenya Agricultural and Livestock Research Organization, Food Crops Research Institute-Embu, Embu, Kenya \\ ${ }^{2}$ Department of Plant Science and Crop Protection, Faculty of Agriculture, University of Nairobi, Nairobi, \\ Kenya \\ ${ }^{3}$ International Center for Research and Education in Agriculture, Nagoya University, Chikusa, Nagoya, Japan \\ ${ }^{4}$ Applied Social System Institute of Asia, Nagoya University, Chikusa, Nagoya, Japan \\ ${ }^{5}$ Kenya Agricultural and Livestock Research Organization, Industrial Crops Research Institute-Mwea, Kerugoya, \\ Kenya \\ ${ }^{6}$ Graduate School of Agricultural Science, Kobe University, Nada, Kobe, Japan \\ Correspondence: Daigo Makihara, International Center for Research and Education in Agriculture (ICREA), \\ Nagoya University, Chikusa, Nagoya 464-8601, Japan. E-mail: makihara@agr.nagoya-u.ac.jp
}

Received: April 5, 2018

Accepted: March 14, 2019

Online Published: May 15, 2019

doi:10.5539/jas.v11n6p1

URL: https://doi.org/10.5539/jas.v11n6p1

\begin{abstract}
The growth of 20 rice varieties, including both lowland and upland varieties, was evaluated in Kenya under well-watered and water-deficit conditions in four different soil types (black cotton, red clay, volcanic ash, and sandy clay) to compare the adaptability of these varieties to the two water regimes. Under water-deficit condition, after terminating irrigation, the reduction in soil water potential differed markedly according to soil type. The rice varieties tested were classified into four groups, which were largely consistent with differences in rice variety ecotype. We confirmed that lowland varieties such as Basmati 370 should not be considered as a candidate for cultivation under rain-fed upland conditions in Kenya. Furthermore, the results revealed that even potentially high-yielding varieties may not attain their yield potential if the cultivation environment is unsuitable. Although we found that five upland varieties (Dular, IRAT109, NERICA 1, NERICA 4, and Yumenohatamochi) presented relatively higher grain yield under water-deficit conditions in all soil types, individual variety's grain yield depended on the soil type. Their higher yield is attributable to certain root traits and their yield variations to an interactive effect between root development and soil type. Our results indicated that the varieties Dular, IRAT109, NERICA 1, NERICA 4, and Yumenohatamochi are suitable for cultivation under rain-fed upland conditions across the major rice-growing areas in Kenya and that soil type should be considered when selecting varieties for an area's maximum productivity.
\end{abstract}

Keywords: Kenya, rice, soil type, water deficit

\section{Introduction}

In Kenya, approximately $95 \%$ of rice is irrigated and only 5\% is rain-fed (upland) (Muhunyu, 2012). Thus, irrigated lowland represents the major growth environment for rice in Kenya. However, the potential area for rain-fed upland rice has been estimated to be 2,600,000 ha, which corresponds to $4.6 \%$ of the nation's land area (Saito, Ogawa, Makihara, \& Asanuma, 2016). In particular, the central, southeastern coastal, and western areas around Lake Victoria have considerable potential for upland rice production (Saito et al., 2016). Thus, it is possible that rice could be produced widely in Kenya, including areas where upland rice has not been cultivated previously. Expanding the range of upland rice cultivation and improving rice productivity could be effective means to boost domestic rice production in Kenya.

Currently, upland rice productivity under rain-fed conditions is approximately $1 \mathrm{t} \mathrm{ha} \mathrm{h}^{-1}$, whereas the potential productivity is estimated to be approximately $7 \mathrm{t} \mathrm{ha}^{-1}$ (Kenya Ministry of Agriculture, 2008). This actual low rice production per unit area is associated with a lack of high-yielding varieties that can adapt to the cultivation 
environments in Kenya, poor agronomic practices, and limited water availability (Kimani, Tongoona, Derera, \& Nyende, 2011). This situation might have been caused by the relatively limited interest in developing upland or rain-fed rice varieties, because rice production in Kenya is dominated by irrigated lowland rice (Nasuda, Sakurai, Murage, \& Makihara, 2014). Indeed, following the introduction of upland rice varieties in Kenya in the 1980s, there was little progress in the dissemination of upland rice until 2003 when the Africa Rice Centre introduced New Rice for Africa (NERICA) in Kenya (Kimani et al., 2011). Screening of rice varieties for adaptation to upland in Kenya is still ongoing.

Drought poses one of the most important constraints to upland rice production in Kenya (Kimani et al., 2011). To realize stable rain-fed upland rice production, it is important to introduce varieties that are minimally affected by water deficit. Under such conditions, the amount of soil water available for crop growth is strongly affected by soil physical properties (Letey, 1958) such as water permeability and water-holding capacity. The relationship between soil water content and soil penetration resistance is also of importance in this regard, because this relationship differs depending on soil type, and the root system development is suppressed when soil becomes harder with the progression of soil drying (Ghildyal \& Tomar, 1982). In Kenya, soil type varies considerably, affecting areas in which rice is grown (or potentially grown). Thus, in addition to the prevailing climatic conditions, it is equally important to consider the adaptability of varieties to different soil types when selecting varieties.

The objective of this study was to examine how water deficit affects the performance of 20 selected rice varieties grown in four different soil types. The findings will help identify varieties widely adaptable to uplands for different soil types in Kenya.

\section{Methods}

\subsection{Area Description}

The experiment was performed under a rain-out shelter (plastic greenhouse) at the Kenya Agricultural and

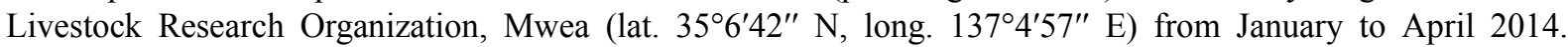
During the experimental period, the monthly mean maximum and minimum temperatures at the experimental site were $27.9-30.8{ }^{\circ} \mathrm{C}$ and $14.5-17.2{ }^{\circ} \mathrm{C}$, respectively.

The experiment comprised two water regimes (well-watered and water deficit), four different soil types, and twenty rice varieties. The experimental design was a split-split plot arranged in a randomized complete block design with three replications. The soil moisture regime was the main plot, the four soil types were the subplots, and the 20 varieties were the sub-subplot factors. Each replication contained four soil types that were arranged randomly. Plants of the 20 varieties were arranged randomly in each plot with eight plants per variety.

\subsection{Material Studied}

Four different soil types, namely, sandy clay, red clay, volcanic ash, and black cotton soils, were collected from different locations, which were considered to be representative of upland rice-growing areas or areas with potential for upland rice cultivation in Kenya. Sandy clay soil was collected from the southeastern costal region where rice has been traditionally cultivated by rain-fed farming. Red clay and black cotton soils were collected from around the Mwea region in Central Kenya, which is the largest rice-producing area in the country. Volcanic ash soil was obtained from the eastern side of Mount Kenya, which was identified as one of the potential areas for upland rice cultivation and a site where dissemination of upland rice has been undertaken.

Twenty varieties of rice were evaluated, including seven traditional varieties sampled from the coastal areas in Kenya (Table 1). These traditional varieties were selected because they are mostly grown in rain-fed lowland conditions in coastal areas and might have the potential for good performance under water-deficit conditions. 
Table 1. Characteristics of the 20 rice varieties examined in the present study

\begin{tabular}{|c|c|c|c|c|c|c|}
\hline No & Variety & Type & Ecosystem & Aroma & Origin (or country where popular) & History \\
\hline 1 & Azucena & Japonica & Upland & Non & Philippines & Improved \\
\hline 2 & Basmati 370 & Indica & Lowland & Aroma & India & Traditional \\
\hline 3 & Dular & Indica & Upland & Non & India & Traditional \\
\hline 4 & IR 2793-80-1 & Indica & Lowland & Non & Philippines & Improved \\
\hline 5 & IRAT 109 & Tropical japonica & Upland & Non & Cote d'Ivoire & Improved \\
\hline 6 & Kinandang Patong & Tropical japonica & Upland & Non & Philippines & Traditional \\
\hline 7 & Lemont & Tropical japonica & Lowland & Non & The U.S. & Improved \\
\hline 8 & NERICA 1 & Interspecific progeny & Upland & Aroma & Côte d'Ivoire & Improved \\
\hline 9 & NERICA 4 & Interspecific progeny & Upland & Non & Côte d'Ivoire & Improved \\
\hline 10 & SARO 5 & Indica & Lowland & Aroma & Tanzania & Improved \\
\hline 11 & ST12 & Indica & Lowland & Non & Japan & Improved \\
\hline 12 & Takanari & Indica & Lowland & Non & Japan & Improved \\
\hline 13 & Yumenohatamochi & Japonica & Upland & Non & Japan & Improved \\
\hline 14 & Coast Kenya-1 & Indica & Lowland & Non & Kenya & Traditional \\
\hline 15 & Coast Kenya-2 & Indica & Lowland & Non & Kenya & Traditional \\
\hline 16 & Coast Kenya-3 & Indica & Lowland & Non & Kenya & Traditional \\
\hline 17 & Coast Kenya-4 & Indica & Lowland & Non & Kenya & Traditional \\
\hline 18 & Coast Kenya-5 & Indica & Lowland & Non & Kenya & Traditional \\
\hline 19 & Coast Kenya-6 & Indica & Lowland & Non & Kenya & Traditional \\
\hline 20 & Coast Kenya-7 & Indica & Lowland & Non & Kenya & Traditional \\
\hline
\end{tabular}

\subsection{Methods}

Twenty-four experimental soil-beds (plots), each of $2.0 \mathrm{~m} \times 2.5 \mathrm{~m}\left(5.0 \mathrm{~m}^{2}\right)$ size, were partitioned with concrete frames. A gravel layer of approximately $5 \mathrm{~cm}$ deep was placed in each compartment, and a 2-mm plastic mesh was laid thereon. Upon this base, the soil was filled to a depth of approximately $30 \mathrm{~cm}$. On December 27, 2013, pre-geminated seeds were sown in soil-filled plastic trays (nursery boxes) and watered. Thirty-three days after sowing, the seedlings were transplanted into the plots at a density of one seedling per hill. The transplanting density was $20 \mathrm{~cm}$ between rows and $20 \mathrm{~cm}$ between plants in a row. In all the soil-beds, soil water was maintained at saturation until plant establishment, and thereafter water management was initiated. In well-watered plots, irrigation was performed daily throughout the growing period to maintain moisture saturation. In water-deficit plots, only when severe leaf rolling in approximately $80 \%$ of the plants was observed, irrigation water was applied to each plot simultaneously until the soil was thoroughly saturated. Basal fertilizer was applied at a rate of $25 \mathrm{~kg} \mathrm{~N}, \mathrm{P}_{2} \mathrm{O}_{5}$, and $\mathrm{K}_{2} \mathrm{O} \mathrm{ha}^{-1}$ in the form of a compound fertilizer (14-14-14), and ammonium sulfate was applied as a top dressing at a rate of $50 \mathrm{~kg} \mathrm{~N} \mathrm{ha}^{-1}$ in two splits.

Changes in soil water potential were regularly recorded using a tensiometer (DIK-3150; Daiki Rika Kogyo Co., Ltd, Saitama, Japan) installed at 20-cm soil depth. At 100-127 d after sowing, three plants were sampled from each plot to determine the above-ground biomass and panicle weight. During sampling, Coast Kenya-1, -2, -3, -4, -5 , and -7; Kinandang Patong; IR 2793-80-1; SARO 5; and ST12 were premature. Therefore, we did not measure the panicle weight for these varieties.

To assess the effects of water regime, soil type, rice variety, and their interactions on panicle weight and above-ground biomass, three-way analyses of variance (ANOVA) was conducted using Statistical Analysis System (version 9.0) (SAS Institute Inc., Cary, NC, USA). The means of panicle weight and above-ground biomass in different water regimes and soil types were separated using the least significant difference (LSD) test at $\mathrm{P}<0.05$ significance. A dendrogram showing clustering of 20 rice varieties based on standardized above-ground biomass was constructed using Ward's method.

\section{Results}

The soil water potential decreased after termination of irrigation in all soil types, except that in sandy clay. However, the decrease observed differed markedly among soil type. At seven days after termination of irrigation, the black cotton soil presented the lowest moisture content $(-25.0 \mathrm{kPa})$, preceded by that of red clay $(-17.5 \mathrm{kPa})$ and volcanic ash $(-14.0 \mathrm{kPa})$, while the water potential of sandy clay was maintained at $0 \mathrm{kPa}$. 
There was a significant effect of soil type, water regime, and variety on panicle weight and above-ground biomass, except for soil type on the panicle weight (Tables 2 and 3). Two-way interactions between water regime and soil type, soil type and variety, and water regime and variety were all significant, except that between water regime and soil type on the panicle weight. However, there was no significant three-way interaction among water regime, soil type, and variety. Irrespective of the soil type and variety, the panicle weight and above-ground biomass under water-deficit conditions were significantly less than that under well-watered condition (Table 4). The panicle weight in volcanic ash soil was significantly higher than that in the black cotton soil. The above-ground biomass in red clay and volcanic ash was higher than that in the other two soils, and the above-ground biomass in black cotton was the lowest among the four soil types.

Table 2. Three-way analysis of variance to determine the effects of water regime (W), soil type (S), rice variety $(\mathrm{V})$, and their interactions on above-ground biomass

\begin{tabular}{|c|c|c|c|c|}
\hline \multirow{2}{*}{ Source of variation } & \multirow{2}{*}{ Degree of freedom } & \multicolumn{3}{|c|}{ Above-ground biomass } \\
\hline & & \multirow[t]{2}{*}{ Mean square } & \multicolumn{2}{|c|}{ Computed F } \\
\hline \multicolumn{4}{|l|}{ Main-plot analysis } & \\
\hline Replication & 2 & 281 & 2.6 & ns \\
\hline $\mathrm{W}$ & 1 & 51180 & 473.9 & $* * *$ \\
\hline Error & 2 & 156 & 1.4 & ns \\
\hline \multicolumn{5}{|l|}{ Sub-plot analysis } \\
\hline $\mathrm{S}$ & 3 & 3646 & 33.8 & $* * *$ \\
\hline $\mathrm{W} \times \mathrm{S}$ & 3 & 618 & 5.7 & $* *$ \\
\hline Error & 12 & 341 & 3.2 & $* *$ \\
\hline \multicolumn{5}{|l|}{ Sub-subplot analysis } \\
\hline $\mathrm{V}$ & 19 & 2550 & 23.6 & $* * *$ \\
\hline $\mathrm{W} \times \mathrm{V}$ & 19 & 804 & 7.4 & $* * *$ \\
\hline $\mathrm{S} \times \mathrm{V}$ & 57 & 237 & 2.2 & $* * *$ \\
\hline $\mathrm{W} \times \mathrm{S} \times \mathrm{V}$ & 57 & 139 & 1.3 & ns \\
\hline Error & 304 & & & \\
\hline Total & 479 & & & \\
\hline
\end{tabular}

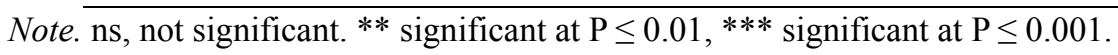

Table 3. Three-way analysis of variance to determine the effects of water regime (W), soil type (S), rice variety (V), and their interactions on panicle weight

\begin{tabular}{|c|c|c|c|c|}
\hline \multirow{2}{*}{ Source of variation } & \multirow{2}{*}{ Degree of freedom } & \multicolumn{3}{|c|}{ Panicle weight } \\
\hline & & Mean square & Comp & ed F \\
\hline \multicolumn{5}{|l|}{ Main-plot analysis } \\
\hline Replication & 2 & 75 & 3.3 & $*$ \\
\hline $\mathrm{W}$ & 1 & 2713 & 117.5 & ${ }^{* * *}$ \\
\hline Error & 2 & 23 & 1.0 & ns \\
\hline \multicolumn{5}{|l|}{ Sub-plot analysis } \\
\hline $\mathrm{S}$ & 3 & 100 & 4.3 & ** \\
\hline $\mathrm{W} \times \mathrm{S}$ & 3 & 31 & 1.3 & ns \\
\hline Error & 12 & 21 & 0.9 & ns \\
\hline \multicolumn{5}{|l|}{ Sub-subplot analysis } \\
\hline $\mathrm{V}$ & 9 & 665 & 28.8 & $* * *$ \\
\hline $\mathrm{W} \times \mathrm{V}$ & 9 & 192 & 8.3 & $* * *$ \\
\hline $\mathrm{S} \times \mathrm{V}$ & 27 & 53 & 2.3 & ** \\
\hline $\mathrm{W} \times \mathrm{S} \times \mathrm{V}$ & 27 & 31 & 1.4 & ns \\
\hline Error & 144 & & & \\
\hline Total & 239 & & & \\
\hline
\end{tabular}

Note. ns, not significant. * significant at $\mathrm{P} \leq 0.05$, ** significant at $\mathrm{P} \leq 0.01, * * *$ significant at $\mathrm{P} \leq 0.001$. 
Table 4. Panicle weight and above-ground biomass under different water regimes and soil types

\begin{tabular}{cllll}
\hline & \multicolumn{3}{l}{ Panicle weight (g per plant) } & Above-ground biomass (g per plant) \\
\hline Water regime & & & & \\
Well-watered & 14.6 & $\mathrm{a}$ & 47.5 & $\mathrm{a}$ \\
Water deficit & 8.6 & $\mathrm{~b}$ & 24.6 & $\mathrm{~b}$ \\
\hline Soil type & 11.3 & $\mathrm{ab}$ & 41.1 & $\mathrm{a}$ \\
Red clay & 12.5 & $\mathrm{a}$ & 40.9 & $\mathrm{a}$ \\
Volcanic ash & 9.7 & $\mathrm{~b}$ & 28.3 & $\mathrm{c}$ \\
Black cotton & 11.6 & $\mathrm{ab}$ & 35.2 & $\mathrm{~b}$ \\
Sandy clay & & & \\
\hline
\end{tabular}

Note. Within each column, the values followed by the same letter are not significantly different at $\mathrm{P}<0.05$.

The dendrogram that was generated from the above-ground biomass of the 20 selected varieties divided the varieties into three clusters (Groups 1-3), and Group 3 was subdivided into two sub-clusters (Groups 3A and Group 3B) (Figure 1). Cluster 1 was mainly composed of the traditional varieties from the coastal areas and other lowland varieties, whereas Cluster 2 comprised improved lowland rice varieties and Cluster $3 \mathrm{~A}$ comprised upland rice varieties. Cluster 3B included varieties developed for cultivation in Africa, namely, NERCA 1, NERICA 4, and SARO 5; a Japanese upland variety, Yumenohatamochi; and a variety with the capacity to develop large numbers of spikelets, ST12.

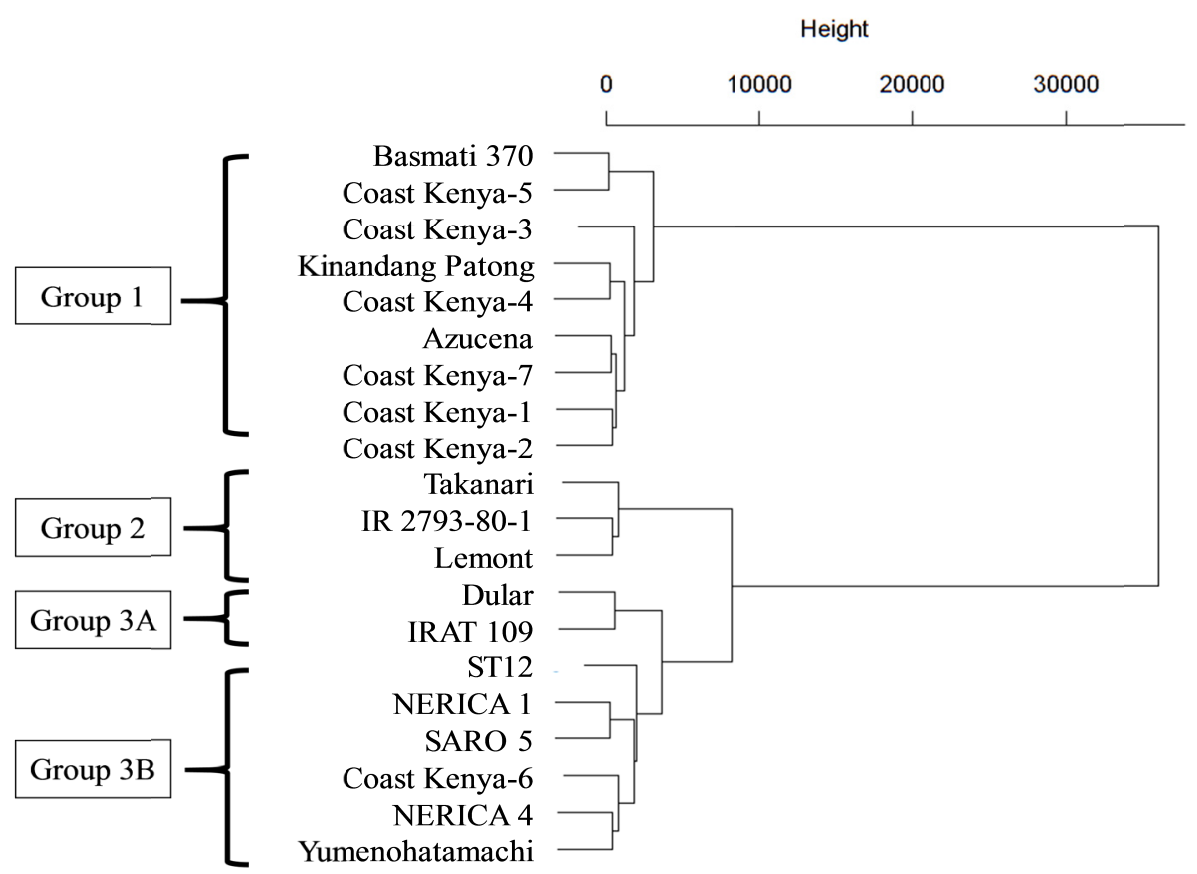

Figure 1. Dendrogram showing clustering of 20 rice varieties based on standardized above-ground biomass

The average above-ground biomass for each soil was 36.8-54.2 $\mathrm{g}$ in well-watered plots and decreased by $45 \%-50 \%$ in plots subjected to water deficit (Table 5). Under well-watered conditions, Group 1 varieties had higher above-ground biomass than that of other Groups in all soil types. With the exception of volcanic ash, under water-deficit conditions, the above-ground biomass of Group 3A varieties in all soils was the highest (27.8-42.4 g), followed by that of Group 1 varieties (21.9-33.8 g), whereas Group 2 varieties presented the lowest above-ground biomass (10.5-15.0 g). Under water-deficit conditions, the above-ground biomass of Kinandang Patong, Coast Kenya-4, Dular, and IRAT109, was consistently high in all soil types except that of Kinandang Patong in black cotton, Coast Kenya-4 in Red soil, and Dular and IRAT109 in volcanic ash. 
Table 5. Above-ground biomass of 20 rice varieties grown in four different soil types under two water regimes

\begin{tabular}{|c|c|c|c|c|c|c|c|c|c|c|c|c|c|c|}
\hline \multirow{3}{*}{ No } & \multirow{3}{*}{ Variety } & \multirow{3}{*}{ Group } & \multicolumn{12}{|c|}{ Above-ground biomass per tiller (g) } \\
\hline & & & \multicolumn{3}{|c|}{ Red soil } & \multicolumn{3}{|c|}{ Volcanic ash } & \multicolumn{3}{|c|}{ Black cotton } & \multicolumn{3}{|c|}{ Sandy } \\
\hline & & & $\begin{array}{l}\text { Well- } \\
\text { watered }\end{array}$ & $\begin{array}{l}\text { Wate } \\
\text { defici }\end{array}$ & & $\begin{array}{l}\text { Well- } \\
\text { watered }\end{array}$ & $\begin{array}{l}\text { Wate } \\
\text { defici }\end{array}$ & & $\begin{array}{l}\text { Well- } \\
\text { watered }\end{array}$ & $\begin{array}{l}\text { Wate } \\
\text { defic }\end{array}$ & & $\begin{array}{l}\text { Well- } \\
\text { watered }\end{array}$ & $\begin{array}{l}\text { Water } \\
\text { deficit }\end{array}$ & \\
\hline 1 & Azucena & 1 & 74.5 & 33.4 & (45) & 65.3 & 33.9 & (52) & 47.0 & 18.3 & (39) & 71.2 & 33.2 & (47) \\
\hline 2 & Basmati 370 & 1 & 77.2 & 30.2 & $(39)$ & 74.7 & 29.7 & $(40)$ & 60.9 & 20.5 & (34) & 37.2 & 19.5 & $(52)$ \\
\hline 6 & Kinandang Patong & 1 & 64.1 & 33.9 & $(53)$ & 62.0 & 34.4 & $(55)$ & 47.1 & 23.2 & (49) & 58.4 & 47.7 & $(82)$ \\
\hline 14 & Coast Kenya-1 & 1 & 69.0 & 38.7 & $(56)$ & 74.0 & 32.6 & (44) & 42.5 & 22.7 & $(53)$ & 47.6 & 25.8 & $(54)$ \\
\hline 15 & Coast Kenya-2 & 1 & 73.7 & 23.6 & (32) & 76.7 & 34.8 & $(45)$ & 40.2 & 14.7 & (37) & 57.7 & 26.4 & (46) \\
\hline 16 & Coast Kenya-3 & 1 & 74.0 & 33.3 & (45) & 92.1 & 29.7 & (32) & 40.5 & 22.2 & (55) & 77.5 & 31.6 & (41) \\
\hline 17 & Coast Kenya-4 & 1 & 72.0 & 28.4 & (39) & 56.5 & 42.8 & (76) & 45.7 & 23.7 & $(52)$ & 61.1 & 39.1 & (64) \\
\hline 18 & Coast Kenya-5 & 1 & 86.2 & 29.9 & (35) & 72.4 & 35.6 & (49) & 57.9 & 28.1 & (49) & 41.2 & 22.2 & $(54)$ \\
\hline 20 & Coast Kenya-7 & 1 & 81.1 & 33.0 & (41) & 63.2 & 31.0 & (49) & 44.3 & 23.6 & (53) & 58.0 & 23.5 & (41) \\
\hline 4 & IR 2793-80-1 & 2 & 12.3 & 11.9 & (97) & 29.6 & 15.9 & (54) & 15.2 & 8.2 & (54) & 30.0 & 13.6 & (45) \\
\hline 7 & Lemont & 2 & 23.0 & 19.8 & $(86)$ & 41.4 & 14.6 & (35) & 18.0 & 17.2 & (96) & 32.0 & 11.3 & (35) \\
\hline 12 & Takanari & 2 & 11.6 & 13.4 & (116) & 26.0 & 7.4 & $(28)$ & 17.5 & 12.0 & (69) & 11.2 & 6.7 & $(60)$ \\
\hline 3 & Dular & $3 \mathrm{~A}$ & 42.1 & 48.1 & (114) & 38.3 & 26.6 & (69) & 38.2 & 24.1 & $(63)$ & 33.2 & 39.9 & (120) \\
\hline 5 & IRAT 109 & $3 \mathrm{~A}$ & 36.8 & 36.7 & $(100)$ & 36.7 & 33.5 & (91) & 24.0 & 31.5 & (131) & 43.4 & 40.8 & (94) \\
\hline 8 & NERICA 1 & $3 \mathrm{~B}$ & 34.5 & 14.1 & $(41)$ & 35.6 & 24.8 & (70) & 39.2 & 21.3 & $(54)$ & 35.5 & 14.2 & (40) \\
\hline 9 & NERICA 4 & $3 \mathrm{~B}$ & 41.9 & 25.6 & (61) & 45.5 & 23.0 & $(51)$ & 32.9 & 19.8 & $(60)$ & 41.4 & 21.4 & $(52)$ \\
\hline 10 & SARO 5 & $3 \mathrm{~B}$ & 36.2 & 14.6 & (40) & 32.4 & 18.6 & (57) & 30.8 & 9.8 & (32) & 30.9 & 19.7 & (64) \\
\hline 11 & ST12 & 3B & 64.0 & 28.1 & (44) & 40.3 & 19.6 & (49) & 48.6 & 22.7 & (47) & 22.2 & 17.4 & (78) \\
\hline 13 & Yumenohatamochi & 3B & 46.1 & 26.1 & (57) & 52.4 & 26.3 & $(50)$ & 17.6 & 12.0 & $(68)$ & 39.9 & 11.8 & $(30)$ \\
\hline \multirow[t]{6}{*}{19} & Coast Kenya-6 & $3 \mathrm{~B}$ & 64.0 & 20.1 & (31) & 47.1 & 22.4 & (48) & 27.2 & 16.4 & (60) & 53.4 & 22.2 & (42) \\
\hline & Group 1 & & 74.7 & 31.6 & $(42)$ & 70.7 & 33.8 & $(48)$ & 47.3 & 21.9 & (46) & 56.6 & 29.9 & (53) \\
\hline & Group 2 & & 15.6 & 15.0 & $(96)$ & 32.3 & 12.7 & (39) & 16.9 & 12.5 & (74) & 24.4 & 10.5 & (43) \\
\hline & Group 3A & & 39.5 & 42.4 & (107) & 37.5 & 30.1 & $(80)$ & 31.1 & 27.8 & (89) & 38.3 & 40.4 & (105) \\
\hline & Group 3B & & 47.8 & 21.4 & $(45)$ & 42.2 & 22.4 & $(53)$ & 32.7 & 17.0 & $(52)$ & 37.2 & 17.8 & $(48)$ \\
\hline & Average & & 54.2 & 27.1 & $(50)$ & 53.1 & 26.9 & $(51)$ & 36.8 & 19.6 & $(53)$ & 44.1 & 24.4 & (55) \\
\hline
\end{tabular}

Note. Numbers in parentheses indicate, for each variety, the above-ground biomass under water-deficit condition relative to that under well-watered condition.

The average panicle weight for each soil was $12.2-17.0 \mathrm{~g}$ in well-watered plots and decreased by $40 \%-53 \%$ in plots subjected to water deficit (Table 6). Irrespective of soil type, the panicle weight of Groups 1 and 2 varieties under water-deficit conditions was lower (1.3-4.3 g) than the average of all varieties (7.3-8.6 g), whereas Group $3 \mathrm{~A}$ varieties presented the highest panicle weight (13.8-21.4 g). In red soil, the higher relative values of panicle weight for Lemont and Takanari were due to abnormally small panicle of both varieties under well-watered conditions. Hence, they were not considered as drought resistant. On the contrary, the panicle weight of Dular was not reduced by water deficit, except that of plants grown in black cotton soil. In all soil types, the panicle weight of IRAT109 was less affected by water deficit. In the other upland varieties, NERICA 1, NERICA 4, and Yumenohatamochi, the panicle weight was reduced under water-deficit conditions in all soil types. The effect of water-deficit conditions on the panicle weight of NERICA 1 was higher when grown in red clay and sandy clay soils, whereas the panicle weight of Yumenohatamochi grown in sandy clay soil was markedly reduced under water-deficit conditions. The four best varieties with respect to panicle weight for red clay and volcanic ash under well-watered conditions were Yumenohatamochi, NERICA 4, Basmati 370, and IRAT109 (19.3-29.1 g), whereas under water-deficit conditions, Dular, IRAT109, NERICA 4, and Yumenohatamochi presented the highest panicle weight (10.8-21.9 g). For black cotton soil, the four best varieties under well-watered conditions were Dular, NERICA 1, NERICA 4, and Basmati 370 (18.0-20.4 g), whereas Dular, IRAT109, NERICA 1, and NERICA 4 varieties were the best (9.8-16.7 g) under water-deficit conditions. For sandy clay, the four best varieties under well-watered conditions were IRAT109, NERICA 1, NERICA 4, and Yumenohatamochi (17.6-25.2 g), and those under water-deficit conditions were Dular, IRAT109, NERICA 1, and NERICA 4 $(5.3-24.2 \mathrm{~g})$. 
Table 6. Panicle weight of 10 rice varieties that reached full maturity at the time of sampling, grown in four different soil types under two water regimes

\begin{tabular}{|c|c|c|c|c|c|c|c|c|c|c|c|c|c|c|}
\hline \multirow{3}{*}{ No } & \multirow{3}{*}{ Variety } & \multirow{3}{*}{ Group } & \multicolumn{12}{|c|}{ Panicle weight per hill (g) } \\
\hline & & & \multicolumn{3}{|c|}{ Red soil } & \multicolumn{3}{|c|}{ Volcanic ash } & \multicolumn{3}{|c|}{ Black cotton } & \multicolumn{3}{|c|}{ Sandy } \\
\hline & & & \multirow{2}{*}{$\begin{array}{l}\begin{array}{l}\text { Well- } \\
\text { watered }\end{array} \\
7.9\end{array}$} & \multicolumn{2}{|c|}{$\begin{array}{l}\text { Water } \\
\text { deficit }\end{array}$} & \multirow{2}{*}{$\begin{array}{l}\begin{array}{l}\text { Well- } \\
\text { watered }\end{array} \\
8.1\end{array}$} & \multicolumn{2}{|c|}{$\begin{array}{l}\text { Water } \\
\text { deficit }\end{array}$} & \multirow{2}{*}{$\begin{array}{l}\begin{array}{l}\text { Well- } \\
\text { watered }\end{array} \\
8.9\end{array}$} & \multicolumn{2}{|c|}{$\begin{array}{l}\text { Water } \\
\text { deficit }\end{array}$} & \multirow{2}{*}{$\begin{array}{l}\begin{array}{l}\text { Well- } \\
\text { watered }\end{array} \\
7.8\end{array}$} & \multicolumn{2}{|c|}{$\begin{array}{l}\text { Water } \\
\text { deficit }\end{array}$} \\
\hline 1 & Azucena & 1 & & 3.7 & (47) & & 5.4 & (67) & & 1.7 & (20) & & 2.7 & (34) \\
\hline 2 & Basmati 370 & 1 & 19.8 & 0.8 & (4) & 24.5 & 0.1 & (1) & 20.4 & 0.8 & (4) & 7.0 & 0.0 & - \\
\hline 7 & Lemont & 2 & 2.7 & 2.8 & (104) & 13.1 & 2.6 & (20) & 5.5 & 4.2 & (76) & 9.4 & 1.2 & (13) \\
\hline 12 & Takanari & 2 & 2.7 & 4.7 & (176) & 8.3 & 3.3 & $(40)$ & 5.7 & 4.4 & (76) & 4.0 & 2.9 & (72) \\
\hline 3 & Dular & $3 \mathrm{~A}$ & 14.8 & 21.9 & (148) & 11.1 & 11.9 & (106) & 18.9 & 11.0 & (58) & 13.9 & 18.6 & (134) \\
\hline 5 & IRAT 109 & $3 \mathrm{~A}$ & 19.3 & 19.4 & (100) & 20.6 & 16.8 & (82) & 13.7 & 16.7 & (122) & 25.0 & 24.2 & (97) \\
\hline 8 & NERICA 1 & 3B & 15.2 & 3.1 & (20) & 18.0 & 10.7 & (59) & 18.0 & 10.6 & (59) & 17.6 & 5.3 & (30) \\
\hline 9 & NERICA 4 & 3B & 22.9 & 10.8 & (47) & 25.4 & 12.6 & (50) & 18.3 & 9.8 & (53) & 25.2 & 10.3 & (41) \\
\hline 19 & Coast Kenya-6 & $3 \mathrm{~B}$ & 14.1 & 0.7 & (5) & 11.9 & 2.9 & (24) & 3.4 & 0.0 & - & 12.7 & 0.0 & - \\
\hline \multirow[t]{6}{*}{13} & Yumenohatamochi & $3 \mathrm{~B}$ & 26.7 & 13.1 & (49) & 29.1 & 13.6 & (47) & 9.0 & 6.3 & (70) & 23.7 & 3.8 & (16) \\
\hline & Group 1 & & 13.8 & 2.2 & (16) & 16.3 & 2.8 & (17) & 14.6 & 1.3 & (9) & 7.4 & 2.7 & (36) \\
\hline & Group 2 & & 2.7 & 3.7 & (137) & 10.7 & 2.9 & (27) & 5.6 & 4.3 & (77) & 6.7 & 2.1 & (31) \\
\hline & Group 3A & & 17.0 & 20.6 & (121) & 15.9 & 14.3 & (90) & 16.3 & 13.8 & (85) & 19.4 & 21.4 & (110) \\
\hline & Group 3B & & 19.7 & 6.9 & (35) & 21.1 & 9.9 & (47) & 12.2 & 8.9 & (73) & 19.8 & 6.5 & (33) \\
\hline & Average & & 14.6 & 8.1 & (55) & 17.0 & 8.0 & (47) & 12.2 & 7.3 & (60) & 14.6 & 8.6 & (59) \\
\hline
\end{tabular}

Note. Numbers in parentheses indicate, for each variety, the panicle weight under water-deficit condition relative to that under well-watered condition.

The relationship between the above-ground biomass and panicle weight varied according to the Groups 1, 2, 3A, and $3 \mathrm{~B}$ grown in each soil type under the two water regimes (Figure 2). There was no significant correlation between the above-ground biomass and panicle weight regardless of the water regimes in Group 1 varieties. The above-ground biomass was significantly and positively correlated with the panicle weight under well-watered conditions in Group 2 varieties $(\mathrm{P}<0.01)$. Whereas, a positive correlation between the above-ground biomass and panicle weight was observed under water-deficit conditions in Groups $3 \mathrm{~A}(\mathrm{P}<0.001)$ and $3 \mathrm{~B}(\mathrm{P}<0.01)$ varieties. 

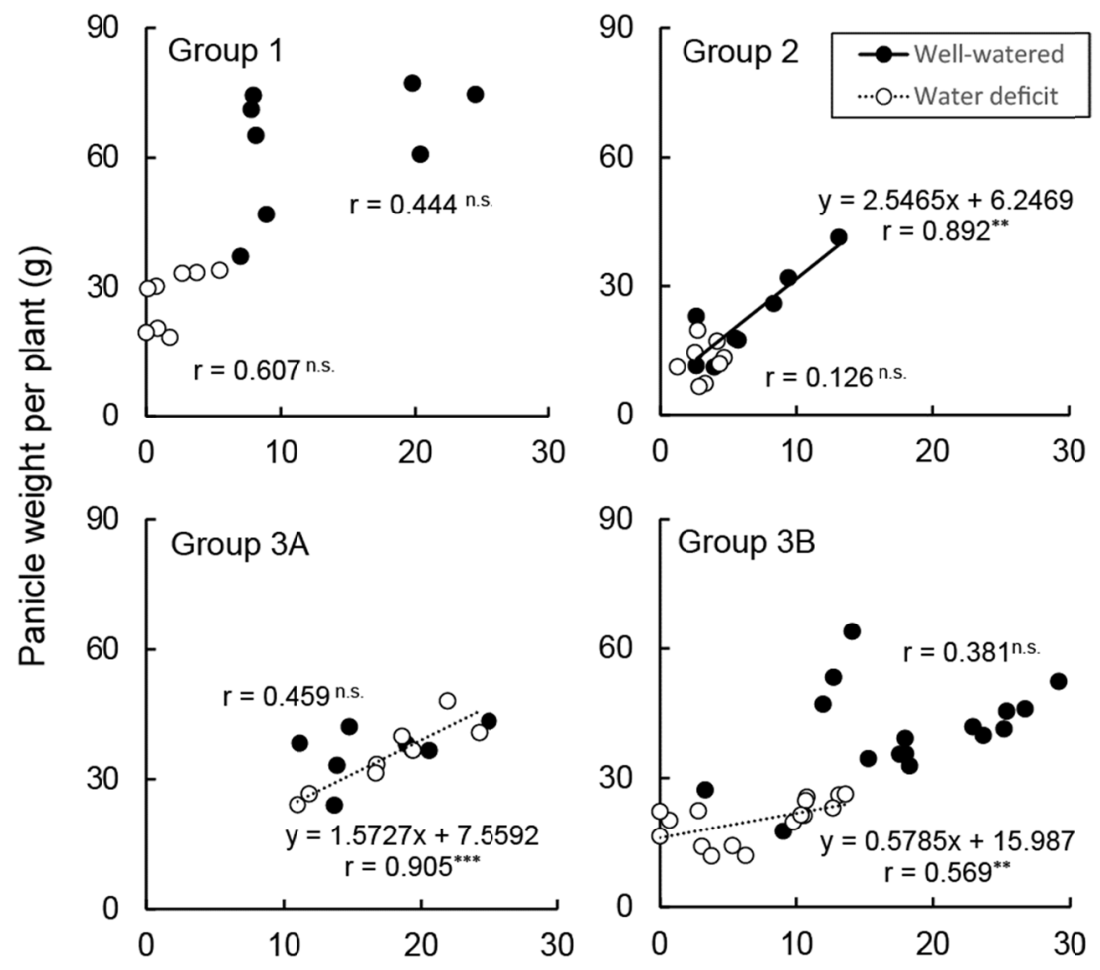

Above-ground biomass per plant $(\mathrm{g})$

Figure 2. Relationship between the panicle weight and above-ground biomass for each rice group under two water regimes

Note. n.s.: not significant, ${ }^{* *}$ : significant at $\mathrm{P}<0.01,{ }^{* * *}$ : significant at $\mathrm{P}<0.001$.

\section{Discussion}

To identify rice varieties adaptability to various cultivation environments in Kenya, we evaluated the performance of 20 rice varieties, including 13 lowland and 7 upland varieties, under well-watered and water-deficit conditions using sandy clay, red clay, volcanic ash, and black cotton soils, representing four major soil types found in Kenya.

Basmati 370 is one of the most popular lowland varieties in Kenya (Kimani et al., 2011; Muhunyu, 2012). Under well-watered conditions in the present study, Basmati 370 presented a higher panicle weight than the average of all varieties in three soil types, except in sandy clay. In contrast, the panicle weight of this variety under water-deficit conditions decreased markedly compared with that under well-watered conditions. Thus, our results revealed that, irrespective of soil type, Basmati 370 is highly susceptible to soil moisture deficiency and should not be cultivated in rain-fed uplands of Kenya.

Fukai, Pantuwan, Jongdee, and Cooper (1999) and Wade et al. (1999) reported that high-yielding varieties may not always exhibit high productivity under field conditions because their complex yield-related traits interact with the cultivation environment. In our study, the panicle weight of Takanari, which have been reported as high-yielding varieties under lowland conditions in Asia, including Japan (Takai et al., 2006), was not higher than that of other varieties under both the water regimes, irrespective of the soil type. This indicates that Takanari are not adapted to Kenyan prevailing climates (possibly air temperature and day length) and soils. These results revealed that even those varieties that have high-yielding potential may not attain potential yields if the cultivation environment is not suitable.

One of the most important characteristics contributing to drought resistance in rice is early maturity (90-100 days after sowing), which is the ability of rice to complete its life cycle before serious plant water deficit develops (Gupta \& O'Toole, 1986; Fukai et al., 1999; Torres, McNally, Cruz, Serraj, \& Henry, 2013). In most upland areas of Kenya, rice can be grown under rain-fed conditions only during a limited period. Farmers sow rice seeds in late March after the beginning of the long rainy season, which ends around late May or early June. To avoid drought during the panicle initiation to heading stages, which are known to be among the growth stages that are 
most sensitive to water stress (Boonjung \& Fukai, 1996), growth duration should be less than 120 days. Thus, selecting an early-maturing variety is one of the most promising strategies for minimizing exposure to extensive drought effects and for securing high grain yields (Bernier, Atlin, Serraj, Kumar, \& Spaner, 2008). Therefore, in our experiment, we set a growth period threshold of approximately 110 days after sowing. Under water-deficit conditions, the coastal varieties, which were included in Group 1, tended to have the second highest above-ground biomass after Group 3A. However, some of the coastal varieties had not attained full maturity under either water regime at the time of plant sampling. Thus, higher above-ground biomass in the coastal varieties did not contribute to an increase in grain yield irrespective of the water regime. Consistent with these observations, Torres et al. (2013) reported that high above-ground biomass may not always guarantee high grain yield under water-deficit conditions. Our results therefore indicated that these coastal varieties would not adapt to rain-fed upland cultivation because of their late maturing characteristics, and thus accordingly may not be suited to the high-altitude areas in Central Kenya.

The selection of drought-resistant varieties under controlled conditions should be based not only on the degree of yield loss caused by drought stress but also on the absolute value of rice yield (Kumar, Bernier, Verulkar, Lafitte, \& Atlin, 2008). A similar tendency was sometimes observed in the present study. For example, the relative value of panicle weight in Yumenohatamochi grown in black cotton soil tended to be higher than that in other soils, whereas the absolute yield was quite low. This indicates that the reduction in rice yield under rain-fed condition is negligible, but cannot contribute to rice production under unsuitable soil type.

Based on the absolute rice production under water-deficit conditions and degree of yield loss caused by water stress, Dular, IRAT109, NERICA 1, NERICA 4, and Yumenohatamochi were selected as potentially suitable varieties under water-deficit conditions across all four soil types. Although all of these five varieties are upland rice, not all the upland rice varieties showed higher productivity under water-deficit conditions (e.g., Azucena and Kinandang Patong). Moreover, the higher panicle weight under water-deficit conditions can be mainly attributed to the higher above-ground biomass indicating that suitable varieties have an ability to maintain dry matter production under water-deficit conditions.

The higher above-ground biomass of rice under limited soil water conditions is associated with root traits such as deep rooting and plasticity in the lateral root development (Henry, 2013; Menge et al., 2016; Tran et al., 2014), which contribute to water and nutrient absorption. With the exception of NERICA 1, the five varieties have been reported to have a deep rooting trait (Ghildyal \& Tomar, 1982; Hirasawa et al., 1998; Nemoto, Suga, Ishihara, \& Okutsu, 1998; Ji et al., 2012; Menge et al., 2016). Deep rooting is considered as one of the most important traits that confer drought resistance because it enables plants to take up water and nutrients from deeper soil layers when shallow soil layers become dry (Yoshida \& Hasegawa, 1982). In addition to the deep rooting system, it is known that in response to changes in soil water conditions, IRAT109 has a greater ability to develop root systems in soil layers where water is available (Araki \& Iijima, 2005). Moreover, it has very thick nodal roots, which is also considered an important trait that contributes to drought resistance (Henry, 2013). On the contrary, NERICA 1 has been reported to have a greater plasticity in lateral root development under moderate drought conditions (Menge et al., 2016). Therefore, it is reasonable to assume that the higher above-ground biomass of the five varieties suitable for water-deficit conditions was associated with the root system. Further study is needed to clarify which root traits contribute to the higher productivity of the top five yielders identified under water-deficit conditions.

In the present study, we also identified interactive effects between rice variety and soil type on panicle weight and above-ground biomass. Moreover, the panicle weight under water-deficit conditions relative to that under well-watered conditions in the top five varieties varied with soil type. These findings indicated that the significant reduction in the yield of rice varieties under water-deficit conditions could be due to the soil type. Cracks in soil caused by drought started to appear at different time points according to soil type, indicating that each soil type could have different physical properties such as soil penetration resistance, water permeability, and water-holding capacity (Letey, 1958; Ghildyal \& Tomar, 1972). Therefore, further studies are needed to investigate the interaction effects between the expression of root traits associated with drought resistance and soil physical properties.

\section{Conclusions}

Five candidate rice varieties, namely Dular, IRAT109, NERICA 1, NERICA 4, and Yumenohatamochi, were found to be potentially suitable for cultivation under rain-fed uplands in Kenya. Among them, IRAT109, which was less affected by water deficit in all the four soil types used, could be the most stable variety for rain-fed upland across the major Kenyan rice-growing areas. In addition, the effect of soil type on rice variety 
productivity indicates that soil type should be considered in rice development projects for maximum productivity. Further studies are required to clarify the mechanisms that underlie the interaction between soil type and rice yield in drought prevailing areas.

\section{Acknowledgements}

This work was supported by the Japan Science and Technology Agency (JST)/Japan International Cooperation Agency (JICA) and the Science and Technology Research Partnership for Sustainable Development (SATREPS).

\section{References}

Araki, H., \& Iijima, M. (2005). Stable isotope analysis of water extraction from subsoil in upland rice (Oryza sativa L.) as affected by drought and soil compaction. Plant and Soil, 270(1), 147-157. https://doi.org/ 10.1007/s11104-004-1304-2

Bernier, J., Atlin, G. N., Serraj, R., Kumar, A., \& Spaner, D. (2008). Breeding upland rice for drought resistance. Journal of the Science of Food and Agriculture, 88(6), 927-939. https://doi.org/10.1002/jsfa.3153

Boonjung, H., \& Fukai, S. (1996). Effects of soil water deficit at different growth stages on rice growth and yield under upland conditions. 2. Phenology, biomass production and yield. Field Crops Research, 48(1), 47-55. https://doi.org/10.1016/0378-4290(96)00039-1

Fukai, S., Pantuwan, G., Jongdee, B., \& Cooper, M. (1999). Screening for drought resistance in rainfed lowland rice. Field Crops Research, 64(1-2), 61-74. https://doi.org/10.1016/S0378-4290(99)00051-9

Ghildyal, B. P., \& Tomar, V. S. (1982). Soil physical properties that affect rice root systems under drought. In J. C. O'Toole (Ed.), Drought resistance in crops with emphasis on rice (pp. 83-96). Los Baños, Philippines: International Rice Research Institute.

Gupta, P. C., \& O’Toole, J. C. (1986). Upland rice: A global perspective. Manila, Philippines: International Rice Research Institute.

Henry, A. (2013). IRRI's drought stress research in rice with emphasis on roots: Accomplishments over the last 50 years. Plant Root, 7, 92-106. https://doi.org/10.3117/plantroot.7.92

Hirasawa, H., Nemoto, H., Suga, R., Ishihara, M., Hirayama, M., Okamoto, K., \& Miyamoto, M. (1998) Breeding of a new upland rice variety "Yumenohatamochi" with high drought tolerance and good eating quality. Breeding Science, 48(4), 415-419. https://doi.org/10.1270/jsbbs1951.48.415

Ji, K., Wang, Y., Sun, W., Lou, Q., Mei, H., Shen, S., \& Chen, H. (2012). Drought-responsive mechanisms in rice genotypes with contrasting drought tolerance during reproductive stage. Journal of Plant Physiology, 169(4), 336-344. https://doi.org/10.1016/j.jplph.2011.10.010

Kimani, J. M., Tongoona, P., Derera, J., \& Nyende, A. B. (2011). Upland rice varieties development through participatory breeding. Journal of Agricultural and Biological Science, 6(9), 39-49.

Kumar, A., Bernier, J., Verulkar, S., Lafitte, H. R., \& Atlin, G. N. (2008). Breeding for drought tolerance: Direct selection for yield, response to selection and use of drought-tolerant donors in upland and lowland-adapted populations. Field Crops Research, 107(3), 221-231. https://doi.org/10.1016/j.fcr.2008.02.007

Letey, J. (1958). Relationship between soil physical properties and crop production. In Advances in Soil Science (pp. 277-294). New York, NY: Springer. https://doi.org/10.1007/978-1-4612-5046-3_8

Menge, D. M., Kameoka, E., Kano-nakata, M., Yamauchi, A., Asanuma, S., Asai H., ... Makihar D. (2016) Drought-induced root plasticity of two upland NERICA varieties under conditions with contrasting soil depth characteristics. Plant Production Science, 19(3), 389-400. https://doi.org/10.1080/1343943X. 2016.1146908

Ministry of Agriculture, Republic of Kenya. (2008). National Rice Development Strategy (2008-2018). Nairobi, Republic of Kenya.

Muhunyu, J. G. (2015). Is Doubling Rice Production in Kenya by 2018 Achievable? Journal of Developments in Sustainable Agriculture, 7(1), 46-54. https://doi.org/10.11178/jdsa.7.46

Nasuda, A., Sakurai, T., Murage, H., \& Makihara, D. (2014). Dual role of irrigation schemes for NERICA diffusion in the Central Highlands in Kenya: Sources of supplemental water and technology information. Journal of International Cooperation for Agricultural Development, 13, 29-37.

Nemoto, H., Suga, R., Ishihara, M., \& Okutsu, Y. (1998). Deep rooted rice varieties detected through the observation of root characteristics using the trench method. Breeding Science, 48, 321-324. 
Saito, G., Ogawa, S., Makihara, D., \& Asanuma, S. (2016). Estimation of potential area for upland rice production in Kenya. Upland Farming, 676, 9-22.

Takai, T., Matsuura, S., Nishio, T., Ohsumi, A., Shiraiwa, T., \& Horie, T. (2006). Rice yield potential is closely related to crop growth rate during late reproductive period. Field Crops Research, 96(2-3), 328-335. https://doi.org/10.1016/j.fcr.2005.08.001

Torres, R. O., McNally, K. L., Cruz, C. V., Serraj, R., \& Henry, A. (2013). Screening of rice Genebank germplasm for yield and selection of new drought tolerance donors. Field Crops Research, 147, 12-22. https://doi.org/10.1016/j.fcr.2013.03.016

Tran, T. T., Kano-Nakata, M., Takeda, M., Menge, D., Mitsuya, S., Inukai, Y., \& Yamauchi, A. (2014). Nitrogen application enhanced the expression of developmental plasticity of root systems triggered by mild drought stress in rice. Plant and Soil, 378(1-2), 139-152. https://doi.org/10.1007/s11104-013-2013-5

Wade, L. J., McLaren, C. G., Quintana, L., Harnpichitvitaya, D., Rajatasereekul, S., Sarawgi, A. K., ... Sarkarung, S. (1999). Genotype by environment interactions across diverse rainfed lowland rice environments. Field Crops Research, 64(1-2), 35-50. https://doi.org/10.1016/S0378-4290(99)00049-0

Yoshida, S., \& Hasegawa, S. (1982). The rice root system: its development and function. Drought Resistance in Crops with Emphasis on Rice (pp. 97-114). Los Baños, Philippines: International Rice Research Institute.

\section{Copyrights}

Copyright for this article is retained by the author(s), with first publication rights granted to the journal.

This is an open-access article distributed under the terms and conditions of the Creative Commons Attribution license (http://creativecommons.org/licenses/by/4.0/). 